DOI:10.17951/h.2020.54.1.53-66

\begin{tabular}{lcc}
\hline \multicolumn{3}{c}{ A N N A L E S } \\
UNIVERSITATIS MARIAE CURIE-SKŁODOWSKA \\
LUBLIN - POLONIA \\
VOL. LIV, 1 & SECTIOH H \\
\hline
\end{tabular}

\title{
OLEH KUZMIN
}

oleh.y.kuzmin@lpnu.ua

Lviv Polytechnic National University

12 Stepan Bandera St., Lviv Oblast, 79000

ORCID ID: https://orcid.org/0000-0002-6014-6437

NATALIA STANASIUK

ovssns@ukr.net

Lviv Polytechnic National University

12 Stepan Bandera St., Lviv Oblast, 79000

ORCID ID: https://orcid.org/0000-0002-6885-9431

\section{Assessment of the Financial and Investment Components of Industrial Potential}

Keywords: industrial potential; financial and investment component; economic evaluation; indicators, development level

JEL: F65

How to quote this paper: Kuzmin, O., \& Stanasiuk, N. (2020). Assessment of the Financial and Investment Components of Industrial Potential. Annales Universitatis Mariae Curie-Skłodowska, sectio H-Oeconomia, Vol. 54, No. 1.

\footnotetext{
Abstract

Theoretical background: The need for national industrial revival requires the assessment process of the financial and investment components of industrial potential, since such process allows for the development of a further strategy of industrial development of the country, taking into account the available opportunities as well as implementing effective government controls aimed at increasing the competitiveness of the national economy.

Purpose of the article: The development of a methodological foundation for a complex economic assessment of financial and investment components of industrial potential.
} 
Research methods: A comparative analysis was used to study methodological approaches to the economic assessment of potential, laying the groundwork for conceptual foundations of a comprehensive economic evaluation of the financial and investment components. The types of analysis used were: a system analysis to set the system of assessment indices and indicators of financial and investment components of industrial potential; an integral assessment analysis - to determine the integral levels of the potential development for certain types of industrial activity based on standardisation of indicators reflecting the development of financial and investment components; a statistical analysis - to identify changes in the development level of the financial and investment components of potential for certain types of industrial activity; and an abstract-logical analysis to draw conclusions and formulate theoretical generalisation of the obtained results.

Main findings: Our research collected the experiences of former scientists and developed methodological bases in order to study industrial potential as a complex economic category, the development of which is conditioned by the development level of its financial and investment components. The authors' approach to a comprehensive economic assessment of the financial and investment components of industrial potential is based on the identification of both input and output indicators. Such allocations allowed the determining of the reproductive potential of the financial and investment components as a potential opportunity to attract relevant resources, as well as implemented potential, which characterises the effectiveness of their use (the opportunity used). Next, the input indicators were further split into general indicators - which are characterised by quantitative parameters of the scope of the resources, and reflect the involvement scale - and partial indicators, which reflect the qualitative resources characteristics. The proposed integrated indicators of the development levels of financial and investment components have a complex hierarchical structure. For example, the first level generates a set of indicators that provide for a qualitative and quantitative assessment of the development state, the second level determines the integral indices in terms of individual types of indicators, while the third level is based on the potential type (reproductive and implemented). A modified Harrington's scale was proposed to draw a conclusion on the development level achieved for the financial and investment components of industrial potential. Research was conducted using the methodology proposed, on the development levels of financial and investment components of potential for various types of industrial activity. The results showed the existence of a high level of both reproductive and implemented potential in the production of computers, electronics and optical devices, and basic pharmaceutical products, which demonstrates the technological progress in the structural industrial potential transformation. The proposed methodological approach will allow for the definition of a "critical area" in the financial and investment components development necessary for the adoption of appropriate management decisions with regard to adjusting industrial potential development strategies.

\section{Introduction}

In economic theory, the issue of evaluating industrial potential and its financial and investment components as the fundamental basis for its development is a controversial issue due to the complexity and versatility of the object being evaluated. The multidirectionality of existing methodological approaches does not contribute to the formation of objective assessments and reduces the managerial performance of the economic industrial sector. The generation of an extensive array of indicators characterising the development of the financial and investment components of industrial potential determines the need for their systematisation in the indicators' search direction, which will allow for the most complete description of the research object in order to identify problem areas and develop effective measures aimed at their elimination. The selection of indicators is one of the most challenging tasks, as they should become signals for the timely prevention of adverse downturns in the economic industrial sector. 
The purpose of this research is to improve the theoretical, methodological, methodical and applied principles for economic evaluation of the financial and investment component of industrial potential as the basis for its development. The following tasks were set in order to achieve this purpose:

- systematising and generalising existing methodological approaches to assess industrial potential and its financial and investment components,

- developing methodological principles for integrated economic assessment of financial and investment components of industrial potential; and

- analysing the developmental level of financial and investment components of potential in certain types of industrial activities.

\section{Literature review}

Given this issue significance, studies by many scientists have dealt with determining the potential value, development indicators of its financial and investment components (Blank, 2008; Burdina, Kaloshina, \& Chiznik, 2017; Csikosova, Janoskova, \& Culkova, 2019; Dahlam, Ramlawati, \& Lamatinula, 2017; Grynko \& Smyrnov, 2014; Jang \& Kim, 2017; Jiang, Wang, Li, Wang, \& Huang, 2019; Kirilova, 2012; Kocmanova \& Docekalova, 2015; Kovalchuk \& Dudchenko, 2019; Kuck, 2017; Mabert \& Watts, 2005; Mileris, 2010; Monitor \& Outlook, 2012; Nechitaylo, 2010; Orsag \& McClure, 2013; Primasari \& Setyohadi, 2017; Suhodeev, 2013; Taranyuk, 2014; Tyutyunnyk \& Tyutyunnyk, 2016; Włodarczyk, Heller, \& Ostrowska, 2018; Wu \& Pan, 2019).

As a result of the detailed elaboration of these works, it has been established that a resource approach to this potential assessment has been one of the most studied approaches in modern literature, and is based on a variety of resources necessary for the formation and development of financial and investment components. Financial potential is considered as the ability to optimise the financial system by attracting and using financial resources (Kirilova, 2012, p. 298; Kocmanova \& Docekalova, 2015, p. 1387; Wu \& Pan, 2019, p. 3295). The representatives of the resource-efficient approach offer to assess the financial and investment components by using the indicators of the maximum possible sales volume, obtaining cumulative effects from the activity, determining the economic performance, and the effective strength of the investment projects (Dahlam, Ramlawati, \& Lamatinula, 2017, pp. 253-258; Jang \& Kim, 2017, p. 330; Mileris, 2010, pp. 1078-1084; Nechitaylo, 2010, pp. 13-19; Orsag \& McClure, 2013, pp. 71-77; Primasari \& Setyohadi, 2017, p. 51). Followers of the cost-resource approach adhere to the position that the potential assessment is associated with the costs of its formation and development, which often leads to an inappropriate use of resources. This approach is feasible only when comparing the similar indicators, results obtained, etc. For example, in order to estimate the financial component of industrial potential, indicators are used that characterise the value of intangible assets, fixed assets, construction in progress, long-term financial 
investments, accounts receivable, cash and cash equivalents, long-term and current liabilities, gross and net profit, and bank loans (Kuck, 2017, p. 89; Taranyuk, 2014, p. 99). The typical stage of the evaluation of industry potential is the normalisation of the indicators by comparing them with the reference values, which allows for their standardisation.

Kozik and Lesik (2014,p. 176) attempted to synthesise cost-effective approaches to potential assessment and proposed to use the amount of profit derived from their implementation as a general indicator of the corporate endogenous economic potential. The indicators of liquidity, profitability, turnover, financial stability, creditworthiness, etc. are used in terms of reproductive approach to the financial component assessment (Blank, 2008; Csikosova, Janoskova, \& Culkova, 2019, pp. 9-15; Mabert \& Watts, 2005, pp. 52-70; Monitor \& Outlook, 2012, pp. 27-29; Tyutyunnyk \& Tyutyunnyk, 2016, pp. 421-428).

Grynko and Smyrnov (2014) proposed a three-stage (preparatory, estimated, final stages) model of the financial and investment potential assessment based on the integral indicator calculation with a four-level ranking (high, middle, low and zero levels). Based on the achieved development level of the financial and investment components, a further corporate development strategy was formed.

Critical analysis of the considered methodological approaches to the assessment of economic potential and its individual types became the basis for developing the economic evaluation conceptual framework for financial and investment components of industrial potential (Table 1).

Table 1. Conceptual framework of the economic evaluation for financial and investment components of industrial potential

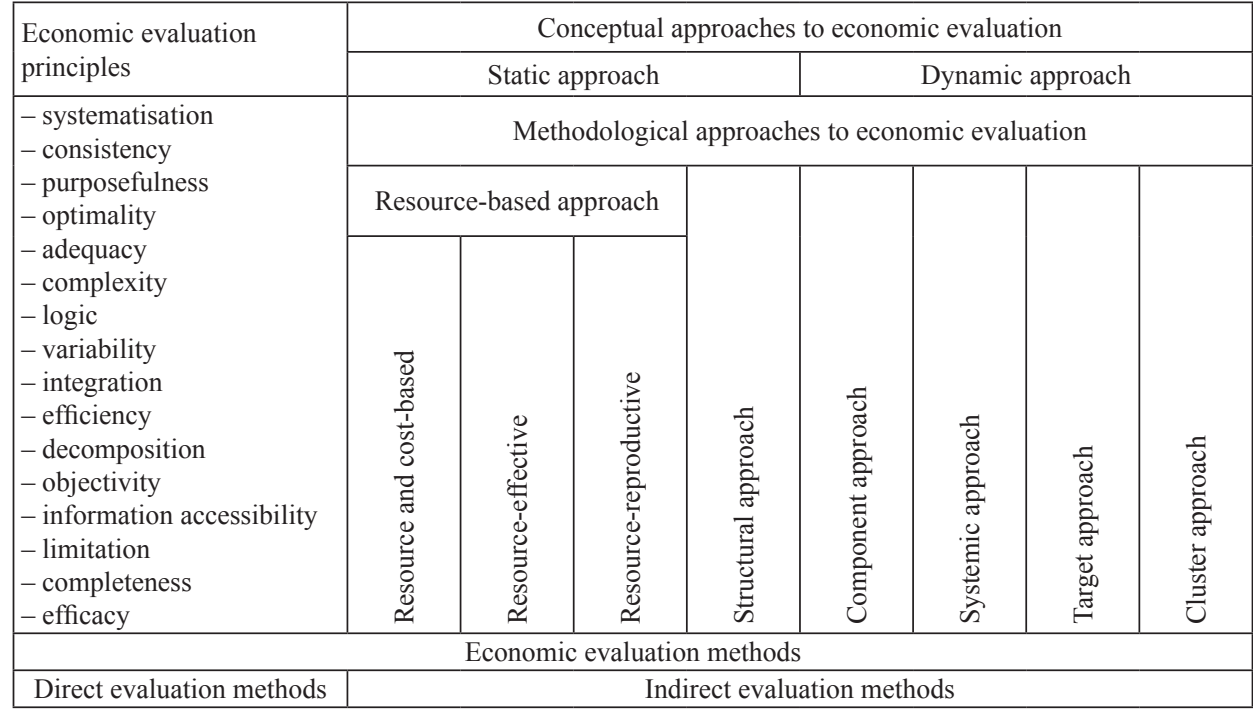

Source: Authors' own study. 


\section{Research methods}

The development of an economic evaluation methodology for financial and investment components of industrial potential involves consistent implementation of the following stages (Figure 1).

It should be noted that in terms of the economic essence, the "industrial potential" category has a dualistic interpretation, since we have a set of resources as an input, and the result as an output. This basic category of dualistic differentiation became the basis for distinguishing input and output development indicators for the financial and investment components of industrial potential. In order to assess the development level of the financial and investment components of industrial potential, we suggest dividing the input indicators into two groups: general indicators, which characterise its development scope, and partial indicators, which allow the revealing of component-specific features.

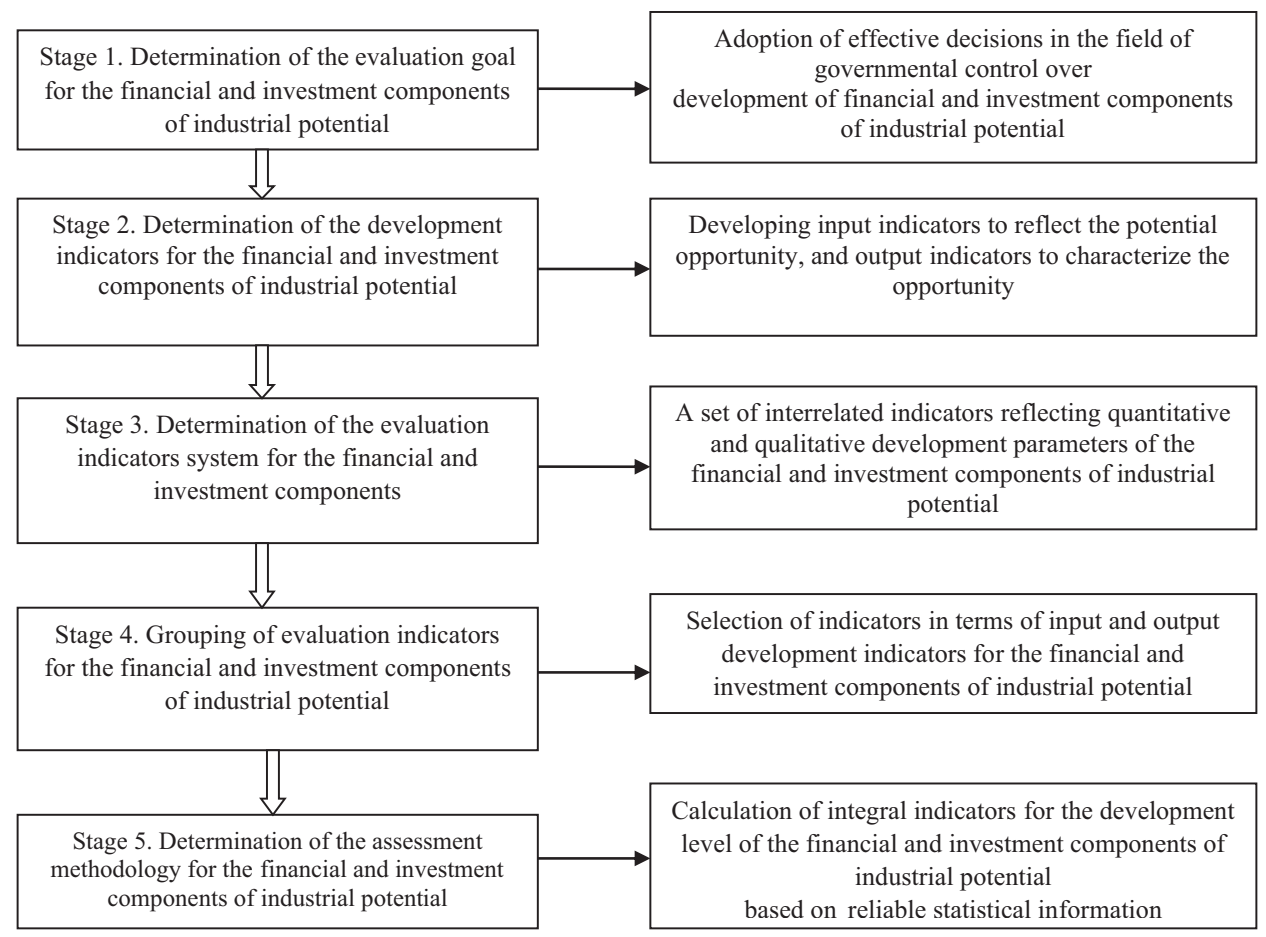

Figure 1. Methodological development stages for economic evaluation of the financial and investment components of industrial potential

Source: Authors' own study.

Scope indicators characterise the extent of the involvement of financial and investment resources for the reproductive potential formation represented, in general, 
by absolute indicators (volume of industrial products sold, investments volume, etc.). Partial indicators allow the assessment of a resource's suitability for reproduction, serving as qualitative criteria for the development of financial and investment components. Thus, the financial and investment components' indicators include the financial standing indicators of industrial enterprises (liquidity, financial stability, business activity, etc.), which collectively characterise the financial capacity of a particular type of industrial activity, as well as an investment attractiveness indicator reflecting the level of investor interest for investing in various types of industrial activities.

Based on the input data taken from the information database of the Main Department of Statistics of Ukraine, the multi-criteria indicators system for a comprehensive economic evaluation of the financial and investment components of industrial potential in terms of input and output indicators are shown in Table 2.

Table 2. Multi-criteria indicators system for economic evaluation of the financial and investment components of industrial potential

\begin{tabular}{|c|c|c|}
\hline $\begin{array}{l}\text { Indicator } \\
\text { group }\end{array}$ & Indicator type & Indicator \\
\hline \multirow{5}{*}{$\begin{array}{l}\text { Input indica- } \\
\text { tors }\end{array}$} & Scope & $\begin{array}{l}\text { Volume of industrial products sold (USD) } \\
\text { Volume of capital investments (USD) }\end{array}$ \\
\hline & Liquidity & $\begin{array}{l}\text { Total liquidity ratio } \\
\text { Quick liquidity ratio } \\
\text { Absolute liquidity ratio } \\
\end{array}$ \\
\hline & Business solvency & $\begin{array}{l}\text { Equity ratio } \\
\text { Leverage ratio } \\
\text { Current assets to equity ratio } \\
\text { Long-term investments purposefulness ratio }\end{array}$ \\
\hline & Business activity & $\begin{array}{l}\text { Asset turnover ratio } \\
\text { Accounts payable turnover ratio } \\
\text { Average maturity of payables, days } \\
\text { Receivable turnover } \\
\text { Average maturity of receivables, days } \\
\text { Production reserves turnover ratio } \\
\text { Average production reserves turnover, days } \\
\text { Equity turnover ratio } \\
\text { Fixed assets turnover ratio }\end{array}$ \\
\hline & $\begin{array}{l}\text { Investment attractive- } \\
\text { ness }\end{array}$ & $\begin{array}{l}\text { Capital assets investment level } \\
\text { Share of direct foreign investments in total investments (\%) } \\
\text { Industrial projects investment attractiveness ratio }\end{array}$ \\
\hline \multirow{2}{*}{$\begin{array}{l}\text { Output indi- } \\
\text { cators }\end{array}$} & Performance & $\begin{array}{l}\text { Financial results of activity (USD) } \\
\text { Share of profitable enterprises (\%) }\end{array}$ \\
\hline & Efficiency & $\begin{array}{l}\text { Level of industrial enterprises profitability (\%) } \\
\text { Operating profitability level (\%) } \\
\text { Profit-to-investment ratio }\end{array}$ \\
\hline
\end{tabular}

Source: Authors' own study. 
At the same time, the presence of absolute and relative indicators with different units of measurement, which represent the state and development of the financial and investment component of industrial potential, necessitates their standardisation, which can be performed using the following formulas:

$$
\begin{aligned}
& X_{i y}^{I}={ }^{X i j} / X m+1 j \\
& X_{i y}^{I}=X m+1 j / X i j
\end{aligned}
$$

Where:

$i-1,2, \ldots, \mathrm{n}$

$j-1,2, \ldots, \mathrm{n}$

$X_{m+1 j}-j^{\text {th }}$ indicator of industrial reference activity

Formula (1) should be used when the maximum value of the indicator is taken as a benchmark, and formula (2) should be used when the minimum value is a benchmark. Deviation from the benchmark characterises the development level of the financial and investment components in a particular type of industrial activity (Formula 3).

$$
Y_{i y}=1-X_{i j}^{1}
$$

Based on the identified input and output indicators, two integral indices can be defined to determine the reproductive and implemented industrial potential values in terms of the selected components.

To calculate the integral levels of reproductive and implemented potential development for the financial and investment component, we propose to use the following formulas $(4,5)$ :

$$
I_{r p}=\sqrt[4]{I_{s c} \cdot I_{l} \cdot I_{b s} \cdot I_{b a} \cdot I_{\text {inat }}}
$$

Where:

$I_{r p}$ - the integral level of reproductive potential development for financial and investment components

$I_{s c}-$ the integral scale level

$I_{l}$ - the integral liquidity level

$I_{b s}$ - the integral business solvency level

$I_{b a}$ - the integral business activity level

$I_{\text {inat }}-$ the integral investment attractiveness level 
Formula 5 is shown below:

$I_{\text {imp }}=\sqrt{I_{\text {per }} \cdot I_{\text {ecef }}}$.

Where:

$I_{i m p}$ - the integral level of implemented potential development for financial and investment components

$I_{\text {per }}-$ the integral performance level

$I_{\text {ecef }}$ - the integral economic efficiency level

In other words, the economic evaluation of the development level for the financial and investment components involves determining the development level of its reproductive and implemented potentials.

Each of the integral indices development level for reproductive and implemented potential of the financial and investment components has a complex hierarchical structure, since at the initial stage (third level) a variety of indicators is formed. The second level requires their generalisation at the individual indicator level, while the first level is the obtaining of the generalised results by the gradual collapse of the second-level indices. For a clear reflection, a hierarchical structure is given of the integral development indices formation for the financial and investment components of industrial potential shown in Figure 2.

We use the following formula to determine scale, liquidity, business solvency, business activity, performance, and efficiency indices (Formula 6):

$$
I_{j}=\sqrt[n]{\prod_{i=1}^{n} I_{j}}
$$

Where:

$n$ - the number of economic indices used to assess the relevant indicators $I_{j}$ - corresponding indicator index

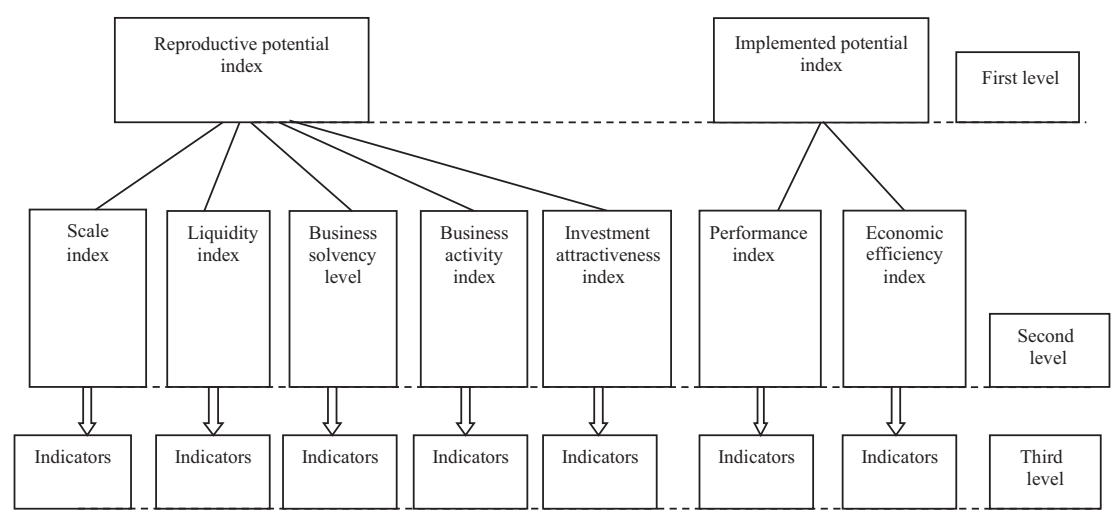

Figure 2. Hierarchical model of the integral indexes structure of the development level for the financial and investment components of industrial potential 
The indicators are summarised using a similar formula in terms of the reproductive and implemented potentials of the financial and investment components of industrial potential. We suggest using the Harrington's scale for economic interpretation of the obtained development levels of reproductive and implemented potentials for the financial and investment components, which provides for different object state levels (Table 3).

Table 3. Application of Harrington's scale to assess the development levels for the financial and investment components of industrial potential

\begin{tabular}{|l|l|l|}
\hline $\begin{array}{c}\text { Scale } \\
\text { intervals }\end{array}$ & $\begin{array}{c}\text { Linguistic } \\
\text { assessment of the } \\
\text { industrial potential } \\
\text { development level }\end{array}$ & Economic interpretation \\
\hline $0-0.2$ & Very high & $\begin{array}{l}\text { A balanced development of the financial and investment components of } \\
\text { industrial potential, which is characterised by high development level indi- } \\
\text { cators of its reproductive and implemented potentials. }\end{array}$ \\
\hline $0.2-0.37$ & High & $\begin{array}{l}\text { Financial and investment components are sufficiently developed, although } \\
\text { slight deviations may be observed in terms of individual indicators. }\end{array}$ \\
\hline $0.37-0.63$ & Average & $\begin{array}{l}\text { Certain negative trends observed in individual indicators that do not have } \\
\text { a threatening significance for development. }\end{array}$ \\
\hline $0.63-0.80$ & Low & $\begin{array}{l}\text { Financial and investment components development is significantly unbal- } \\
\text { anced, significant deviations observed in terms of individual indicators. }\end{array}$ \\
\hline$>0.80$ & Very low & $\begin{array}{l}\text { Deviations of indicators are so significant that they can lead to a potential } \\
\text { loss of financial and investment components. }\end{array}$ \\
\hline
\end{tabular}

Source: Authors' own study,

\section{Results}

Potential industrial development is ensured by the development of its financial and investment components, which in its most general form reflects the financial situation in the industrial sector; and its investment attractiveness level for the industrial production characterises the investment climate in the industrial sector of the national economy and the financial capacity of the industrial enterprises.

Table 4 shows the integral indicators obtained based on the input and output development indicators for the financial and investment components in terms of certain types of processing activities.

Table 4. Integral development levels of the financial and investment components for certain types of manufactured industry potential

\begin{tabular}{|c|c|c|}
\hline \multirow{2}{*}{ Type of activity, period } & \multicolumn{2}{|c|}{ Integral development indices } \\
\cline { 2 - 3 } & Reproductive potential & Implemented potential \\
\hline 1 & 2 & 3 \\
\hline \multicolumn{2}{|c|}{ Production of food, beverages and tobacco products } \\
\hline 2016 & 0.058 & 1.647 \\
\hline 2017 & 0.069 & 1.117 \\
\hline 2018 & 0.129 & 0.616 \\
\hline \multicolumn{2}{|c|}{ Textile production, production of clothes, leather, leather articles and other materials } \\
\hline
\end{tabular}


Pobrane z czasopisma Annales H - Oeconomia http://oeconomia.annales.umcs.pl

Data: 26/04/2023 14:11:29

\begin{tabular}{|c|c|c|}
\hline \multirow{2}{*}{ Type of activity, period } & \multicolumn{2}{|c|}{ Integral development indices } \\
\hline & Reproductive potential & Implemented potential \\
\hline 2016 & 0.132 & 0.700 \\
\hline 2017 & 0.083 & 1.592 \\
\hline 2018 & 0.225 & 0.521 \\
\hline \multicolumn{3}{|c|}{ Production of wood products, paper production and printing activities } \\
\hline 2016 & 0.213 & 0.707 \\
\hline 2017 & 0.230 & 2.247 \\
\hline 2018 & 0.510 & 1.231 \\
\hline \multicolumn{3}{|c|}{ Production of coke and refined products } \\
\hline 2016 & 0.359 & 0.149 \\
\hline 2017 & 0.473 & 0.225 \\
\hline 2018 & 0.654 & 0.188 \\
\hline \multicolumn{3}{|c|}{ Production of chemicals and chemical products } \\
\hline 2016 & 0.454 & 1.532 \\
\hline 2017 & 0.708 & 1.499 \\
\hline 2018 & 0.299 & 0.989 \\
\hline \multicolumn{3}{|c|}{ Production of basic pharmaceutical products and pharmaceuticals } \\
\hline 2016 & 0.342 & 0.003 \\
\hline 2017 & 0.000 & 0.003 \\
\hline 2018 & 0.002 & 0.003 \\
\hline \multicolumn{3}{|c|}{ Production of rubber and plastic products, other non-metallic mineral products } \\
\hline 2016 & 0.237 & 1.034 \\
\hline 2017 & 0.312 & 3.503 \\
\hline 2018 & 0.321 & 1.847 \\
\hline \multicolumn{3}{|c|}{ Metallurgical production, production of finished metal products, except for machinery and equipment } \\
\hline 2016 & 0.406 & 1.294 \\
\hline 2017 & 0.393 & 2.693 \\
\hline 2018 & 0.391 & 1.763 \\
\hline \multicolumn{3}{|c|}{ Production of computers, electronic and optical products } \\
\hline 2016 & 0.280 & 0.701 \\
\hline 2017 & 0.122 & 2.779 \\
\hline 2018 & 0.096 & 0.379 \\
\hline \multicolumn{3}{|c|}{ Production of electrical equipment } \\
\hline 2016 & 0.108 & 0.746 \\
\hline 2017 & 0.308 & 2.952 \\
\hline 2018 & 0.579 & 1.817 \\
\hline \multicolumn{3}{|c|}{ Production of machinery and equipment not classified elsewhere } \\
\hline 2016 & 0.264 & 1.336 \\
\hline 2017 & 0.311 & 2.129 \\
\hline 2018 & 0.332 & 0.902 \\
\hline \multicolumn{3}{|c|}{ Production of motor vehicles, trailers, semi-trailers and other vehicles } \\
\hline 2016 & 0.235 & 0.775 \\
\hline 2017 & 0.389 & 3.193 \\
\hline 2018 & 0.475 & 1.819 \\
\hline \multicolumn{3}{|c|}{ Production of furniture, other products; repair and installation of machinery and equipment } \\
\hline 2016 & 0.118 & 0.572 \\
\hline 2017 & 0.257 & 1.604 \\
\hline 2018 & 0.316 & 1.004 \\
\hline
\end{tabular}

Source: Authors' own study based on (State Statistics Service of Ukraine, 2018). 
The results obtained show that the current production of basic pharmaceutical products and pharmaceuticals, and the production of computers, electronic and optical production is characterised by the best conditions for further development (integral index of the reproductive potential development level for the financial and economic components match as closely as 0 ), reflecting the logical process typical for developed European countries. These activities are characterised by active development of the innovative component (high concentration of innovative active enterprises), which positively affects the development of financial and investment components of industrial potential. They also rank first in terms of the implemented potential development level, which allows them to be classified as priority activities, which in the future should become the basis for the industrial potential development of the particular country.

Dynamic analysis of the reproductive potential development level in terms of certain types of processing industries showed that only the production of chemicals and chemical products is characterised by a positive change (integral index increased by 0.155 ). Other types of processing activity are gradually losing their reproductive capacity due to the low economic attractiveness of labour, the high level of material and technical depreciation, the lack of investment and the low innovation activity of industrial enterprises.

The most negative situation was observed regarding the implemented potential development level of the financial and investment components. Most types of processing activities are loss making and require an active state policy aimed at regulating cash flows. It should be noted that in the European Union countries, the central banks, in crisis conditions, obliged commercial banks to invest approximately $30 \%$ of their capital into the development of strategic economic activities. This practice has been observed in other developed countries around the world. For example, in Japan, the commercial banks had to invest $50 \%$ of investment resources in support of long-term projects, and the United States had the target differentiation implemented of loan rates depending on significance level of investment project to upsurge the national economy.

It should be noted that in recent years, there has been a positive dynamic for the implemented potential development level in Ukraine in high-tech industrial production. For example, this can be seen in the production of chemicals and chemical products (an increase of 0.543 ), the production of computers, electronic and optical products (by 0.322 ) and the production of machinery and equipment (by 0.434 ), as well as in the sectors focused on the manufacture of finished products (food and textile industries). Providing the best reproductive conditions for the development of the financial and investment components of these types of industrial activities will contribute to a reduction in the share of resource-consuming and energy-intensive industrial production and structural modernisation of industrial potential. 


\section{Discussion}

In terms of the hypothetical approach to the economic essence interpretation of industrial potential, it should be considered as an existing and used opportunity. Such a dualistic interpretation of the basic category constituted the basis for developing the author's approach into a comprehensive economic evaluation of the financial and investment components of industrial potential, which involves the allocation of two development levels (reproductive and implemented potentials). Based on determining the reproductive potential development level, we can draw a conclusion regarding the availability and suitability of financial and investment resources in certain types of industrial activity; and based on determining the implemented potential development level we can determine the effectiveness of their uses and their economic efficiency. Our proposed methodological approach is an attempt to synthesise resource-consuming, reproductive and resource-efficient approaches to the economic evaluation of the financial and investment components of industrial potential. The achievement of a balanced interaction of reproductive and implemented potential should become the basis for the development of industrial activities and should pave the way for potential industrial development in the country.

\section{Conclusions}

In conclusion, the concept of integrated economic evaluation of the financial and investment components of industrial potential is based on the following provisions:

- industrial potential has a twofold economic essence (available and used opportunity),

- its development is ensured by the achieved development levels of the reproductive and implemented potential of the financial and investment components.

When conducting a comprehensive economic evaluation of the financial and investment components of industrial potential, we justified the choice of indicators in accordance with the following principles:

- indicators are a formalised identification of input and output development indicators for the financial and investment components of industrial potential by its main types (reproductive and implemented),

- each group of indicators is represented by the main types of industrial activity; and

- all indicators are selected based on the research object in order to factor in its specific aspects.

Accordingly, the comprehensive economic evaluation of the financial and investment components of industrial potential allows us to:

- determine previous reproductive and implemented potentials development levels and to make long-term forecasts,

- make cross-sectoral comparisons in order to optimise structural proportions, 
- evaluate the efficiency of using financial and investment resources by comparing the achieved reproductive and implemented potentials development levels; and

- plan activities aimed at developing industrial potential and improving the efficiency of its financial and investment components.

A comprehensive economic evaluation of the financial and investment components of industrial potential based on the corresponding integral indices by types of industrial activity should constitute the basis for identifying industry priorities for potential industrial development and improving the economic structure of national economies.

The methodological foundation for a comprehensive economic evaluation of the financial and investment components of industrial potential will be developed in further research through building an indicators system that represents the status and changes of other potential components.

\section{References}

Blank, I. (2008). Finansoviy menedgment [Financial Management]. Kyiv: Elga Publishing (in Ukrainian). Burdina, A., Kaloshina, M., \& Chiznik, A. (2017). Comprehensive method of analyzing the investment potential of industrial enterprises. Academy of Strategic Management Journal, 16(2).

Csikosova, A., Janoskova, M., \& Culkova, K. (2019). Prediction of developments in the textile and clothing industry in Slovakia by selected indicators of financial analysis. Fibres and Textiles in Eastern Europe, 27(4), 9-16. doi:10.5604/01.3001.0013.0714

Dahlam, M., Ramlawati, \& Lamatinula. (2017). Identification and determination of priority of key performance indicator of financial perspectives on industry cocoa SMEs in South Sulawesi. IOP Conference Series: Earth and Environmental Science, 175(1), 24 July 2018.

Grynko, T., \& Smyrnov, S. (2014). Metodychni pidkhody do otsinky finansovo-investytsiynoho potentsialu promyslovoho pidpryyemstva [Methodical approaches to the estimation of financial and investment potential of an industrial enterprise]. Effective Economy, 12 (in Ukrainian).

Jang, G., \& Kim, W.-J. (2017). Effects of key financial indicators on earning management in Korea's ready mixed concrete industry. Journal of Applied Business Research, 33(2), 329-342.

doi:10.19030/jabr.v33i2.9905

Jiang, Q., Wang, X., Li, Y., Wang, D., \& Huang, Q. (2019). Financial indicators and stock price movements; The evidence from the finance of China. $13^{\text {th }}$ International Conference on Management Science and Engineering Management, Canada, 5-8 August 2019, 743-758.

Kirilova, L. (2012). Finansovyy potentsial pidpryyemstva ta yoho skladovi [The financial potential of the company and its constituents]. Staliy rozvitok economiky, 11 (in Ukrainian).

Kocmanova, A., \& Docekalova, M. (2015). Evaluation of efficient and inefficient Czech companies operating in the manufacturing industry using financial and non-financial indicators and data envelopment analysis. $26^{\text {th }}$ International Business Information Management Association Conference - Innovation Management and Sustainable Economic Competitive Advantage: From Regional Development to Global Growth, IBIMA 2015; Spain, 11-12 November 2015, 1387-1396.

Kozik, V., \& Lesik, L. (2014). Systema pokaznykiv otsinyuvannya potochnoho rivnya endohennoho ekonomichnoho potentsialu pidpryyemstv [The system of indicators for assessing the current level of endogenous economic potential of enterprises]. Economic Space, 86 (in Ukrainian). 
Kovalchuk, A., \& Dudchenko, V. (2019). Macroeconomic risks: Classified features, methods of measurement, mitigation patterns. Baltic Journal of Economic Studies, 5(1).

doi:10.30525/2256-0742/2019-5-1-81-86

Kuck, J. (2017). Modern management solutions for logistics, finance and human resources in defense and security services. Economics, Entrepreneurship, Management, 4(2), 81-90. doi:10.23939/eem2017.02.081

Mabert, V., \& Watts, C. (2005). Enterprise Applications: Building Best-of-Breed Systems. Stanford: Stanford University Press.

Mileris, R. (2010). Estimation of loan applicants default probability applying discriminant analysis and simple Bayesian classifier. Economics and Management, 15, 1078-1084.

Monitor, F., \& Outlook, R. (2012). Stable disequilibrium: Persistent, large payment surpluses and deficits threaten global long-term economic well-being and financial stability. Finance \& Development, 49(2).

Nechitaylo, I. (2010). Analiz suchasnykh pidkhodiv do vyznachennya investytsiynoho potentsialu rehionu [Analysis of current approaches to determine the investment potential of the region]. Financial Markets \& Securities, 24 (in Ukrainian).

Orsag, S., \& McClure, K. (2013). Modified net present value as a useful tool for synergy valuation in business combinations. UTMS Journal of Economics, 4(2), 71-77.

Primasari, C., \& Setyohadi, D. (2017). Financial analysis and TOPSIS implementation for selecting the most profitable investment proposal in goat farming. $2^{\text {nd }}$ International Conferences on Information Technology, Information Systems and Electrical Engineering, Indonesia, 1-2 November 2017, 51-56.

Suhodeev, D. (2013). Otsinka finansovoho potentsialu [Evaluation of financial capacity]. Finance \& Credit, 532(4) (in Russian).

State Statistics Service of Ukraine. (2018). Retrieved from http://www.ukrstat.gov.ua

Taranyuk, L. (2014). Otsinka ekonomichnoho potentsialu promyslovoho pidpryyemstva pry provedenni reinzhynirynhu biznes-protsesiv [Estimation of the economic potential of an industrial enterprise during the reengineering of business processes]. Mechanism of Economic Regulation, 2, 96-105 (in Ukrainian).

Tyutyunnyk, Y., \& Tyutyunnyk, S. (2016). Mechanism of factor analysis of financial performance indicators across industries. Actual Problems of Economics, 179(5), 421-429.

Włodarczyk, B., Heller, J., \& Ostrowska, A. (2018). Financial aspects of macroeconomic stability: The case of Poland. Annales Universitatis Mariae Curie-Skłodowska, sectio H - Oeconomia, 52(6), 129-140, doi:10.17951/h.2018.52.6.129-140

Wu, S., \& Pan, Q. (2019). Financial cooperative potential between China and Belt and Road countries. Emerging Markets Finance and Trade, 55(14), 3295-3310. doi:10.1080/1540496X.2018.1509207 